\title{
HWWI
}

\section{Migrant Entrepreneurs and Social Capital: A Revised Perspective}

\author{
Andreia Tolciu
}

\section{HWWI Research}

Paper 3-19

by the

HWWI Research Programme

Migration Research Group 
Andreia Tolciu

Hamburg Institute of International Economics (HWWI)

Heimhuder Str. 71 | 20148 Hamburg

Tel +49 (0)4034 0576 - 342 | Fax +49 (0)4034 0576 - 776

tolciu@hwwi.org

HWWI Research Paper

Hamburg Institute of International Economics (HWWI)

Heimhuder Str. 71 | 20148 Hamburg | Germany

Phone +49 (0)40 340576 - 0 | Fax +49 (0)40 340576 - 776

info@hwwi.org|www.hwwi.org

ISSN 1861-504X

Editorial Board:

Thomas Straubhaar (Chair)

Tanja El-Cherkeh

() Hamburg Institute of International Economics (HWWI)

July 2009

All rights reserved. No part of this publication may be reproduced, stored in a retrieval system, or transmitted in any form or by any means (electronic, mechanical, photocopying, recording or otherwise) without the prior written permission of the publisher. 


\title{
Migrant Entrepreneurs and Social Capital: A Revised Perspective
}

\author{
Andreia Tolciu*
}

\begin{abstract}
During the past two decades, considerable attention has been paid to the relationship between migrant entrepreneurship and ethnic social capital. A central idea emerging from the ongoing research is that migrant businesses are created and managed within networks of ethnic interpersonal relations.

This paper challenges the mainstream idea of 'ethnically over-socialized' migrant entrepreneurs, by embedding the concept of social capital in a framework based on economic incentives and bounded rationality. The analysis of 58 recent interviews with Turkish business owners presents, in contrast with the existing literature, a perspective in which migrant entrepreneurs are first and foremost economic actors, who predominantly understand their ethnic social capital as a strategic resource for action.

Furthermore, in a context disentangled of ethnicity and social capital, this paper discusses the necessity of adopting a more differentiated view when comparing migrant to native business owners.
\end{abstract}

Keywords: migrant entrepreneurs; ethnic social capital; bounded rationality

${ }^{*}$ Hamburg Institute of International Economics (HWWI), Heimhuder Str. 71, 20148 Hamburg, Germany | E-mail: tolciu@hwwi.org 


\section{Introduction}

Building on a long history of sociological research, the study of migrant entrepreneurship has generated over the past thirty years a multidisciplinary research agenda. Most of the existing theories have converged on integrating migrant entrepreneurs in a context shaped by factors such as structural conditions on the labor market, legal arrangements and specific group or individual characteristics (Zhou, 2004).

Considerable attention has been paid to disseminating the relationship between migrant entrepreneurship and ethnic social capital. A central idea emerging from this literature is that migrant businesses are created and managed within networks of ethnic interpersonal relations. The ethnic social capital of migrant entrepreneurs has often been praised as a key determinant in the firm creation and daily business practices through the provision of customers, loyal and cheap labor force, and financing (Aldrich and Waldinger, 1990). Moreover, it is suggested that ethnic resources also take up a central position in explaining growth and business success in ethnic enterprises (Light, 1972; Waldinger, 1986; Light and Bonacich, 1988).

However, a limited number of studies offer a different picture by specifying that ethnic social capital can only help firms improve to a certain extent, but does not guarantee the survivability and development of the enterprise (Bates, 1994; Portes and Sensenbrenner, 1993; Basu and Goswami, 1999).

An important attribute of these studies, both revealing the positive and detrimental effects of social capital, is that they extensively display a great interest in the 'ethnic' component of entrepreneurship. The theoretical framework used for the study of the entrepreneurs' social capital seems to begin and end with the 'ethnic' characteristics of the migrant himself or of the group he is without any further reflection assigned to, with the 'ethnic' labor markets, with his 'ethnic' strategies and management style, or with his 'ethnic' cultural background. Rath and Kloosterman(2000, p.663) have criticized this shortcoming by pointing out that: "ethnic loyalties and ethnic markets are assumed to be the hallmark of immigrant entrepreneurship".

Until now, little attention has been paid to aspects emphasizing the 'entrepreneurial' component of migrant entrepreneurship. Furthermore, almost no studies inquire whether and to what extent the social capital of migrant entrepreneurs can be seen as a matter of economic choice, rather than as an ethnic occurrence.

Building on empirical evidence stemming from 58 recent qualitative interviews with Turkish entrepreneurs in Hamburg, this article aims to fill this research gap 
by providing a detailed picture of the ethnic structure of the social capital involved in the business process, and on the entrepreneurs' economic understanding of social capital. The present analysis challenges the mainstream literature by illustrating ethnic social capital as being a matter of bounded rational behavior of migrant entrepreneurs. Furthermore, it provides a counterbalance to previous models developed by researchers who overestimate the importance of cultural factors and ethnicity and neglect the role of economic incentives in individual behavior. By contrasting migrant entrepreneurs with their native counterparts, I stress the idea that migrant entrepreneurs are first and foremost economic actors who do embed their activities in an ethnic environment, but are, like any other entrepreneurs, concerned with economic interests and market related strategies.

The article is organized as follows: the next section briefly presents the concepts, data and methodology relevant for the study. Against the current understanding of social capital in the migrant entrepreneurship literature, the third section discusses the extent to which ethnic social capital is still significant for Turkish entrepreneurs and their businesses. The forth section illustrates social capital as a resource emerging from economic actions rather than from ethnic adherence. By embedding the analysis of social capital and migrant entrepreneurship into an economic framework, I furthermore question whether, in the current context, the delimitation between migrant and native entrepreneurs according to their ethnic backgrounds is still appropriate. The last section summarizes and presents further research perspectives.

\section{Concepts, data and methodology}

A sound analysis of migrant entrepreneurship presumes both an accurate definition and a clear view of how it differs from related concepts such as 'ethnic' or 'immigrant entrepreneurship.' Although so far all terms have been used in an alternative manner, most researchers show a slight preference for the concept of 'ethnic entrepreneurship', which has its roots in the American research tradition. The 'ethnic' component of ethnic businesses is largely understood as " a set of connections and regular patterns of interaction among people sharing common national background or migration experiences" (Waldinger et al. 1990, p.3).

However, the term 'ethnic entrepreneur' has several shortcomings: firstly, as Rath and Kloosterman (2000) point out, the label 'ethnic' somehow implicates a strong 
involvement of the business owner in the ethnic community, which is not applicable for all entrepreneurs. In the researchers' opinion, when using this concept it is not clear whether one refers to the origins of the entrepreneur or to his management strategies. Secondly, in Europe, and particularly in Germany, the term 'ethnic' is not as commonly used, either in academic or in public discourse, as it is in the United States. Following these considerations, for this analysis I use the more neutral term 'migrant entrepreneur.'

Another important conceptual issue regards the differentiation between first and second generation migrants. This is made according to the definition proposed by Portes and Rumbaut (2001): while first generation migrant entrepreneurs are those entrepreneurs born abroad and who arrived in Germany after the age of twelve, second generation migrant entrepreneurs are the business owners born in Germany with at least one immigrant parent, or those who arrived in Germany before the age of twelve. The age delimitation reflects a substantial upbringing in Germany, which is relevant to further analysis.

The present study is based on data stemming from 58 semi-structured interviews with Turkish entrepreneurs conducted in Hamburg between October 2008 and January 2009. The research design rests upon a hybrid strategy, combining elements of small-scale survey and case study techniques. The methods used for approaching the entrepreneurs were random selection from the local Turkish yellow pages, searches in specific locations, and snowballing.

The focus of analysis was set on Turkish entrepreneurs not only because of the size of the community (people with Turkish background represent the largest migrant community both in Germany and in Hamburg) and the visibility of the businesses (for the general public in Germany, Turkish shops are the typical 'migrant enterprises'). More significant were considered the long history of migration, the rich cultural background, and the complex structure of the Turkish community. These aspects can offer valuable insights regarding the interplay between entrepreneurial activities and ethnic social capital, as well as intergenerational changes in entrepreneurial patterns.

Though efforts were made to assure a random selection ${ }^{1}$, several sectors and locations across the city were deliberately included in the sample. Particularly second generation entrepreneurs who founded firms in knowledge intensive sectors were chosen for the survey, in order to get a better overview regarding intergenerational changes. However, the 'traditional' sectors in which migrant entrepreneurs are active, 
such as retail, trade or gastronomy, are well represented in the sample.

Due to the overrepresentation of knowledge intensive sectors, the distribution regarding educational attainment is also marked by a higher proportion of entrepreneurs with tertiary education than would usually be the case. The gender distribution of the sample reflects the situation at the national level, with Turkish women being substantially less involved in entrepreneurial activities than Turkish men. Finally, regarding the spacial distribution of subjects, the study includes equal proportions of entrepreneurs active in neighborhoods with a low, average and high concentration of migrants.

Figure 1: Socio-demographic characteristics of Turkish entrepreneurs in \% (survey sample)

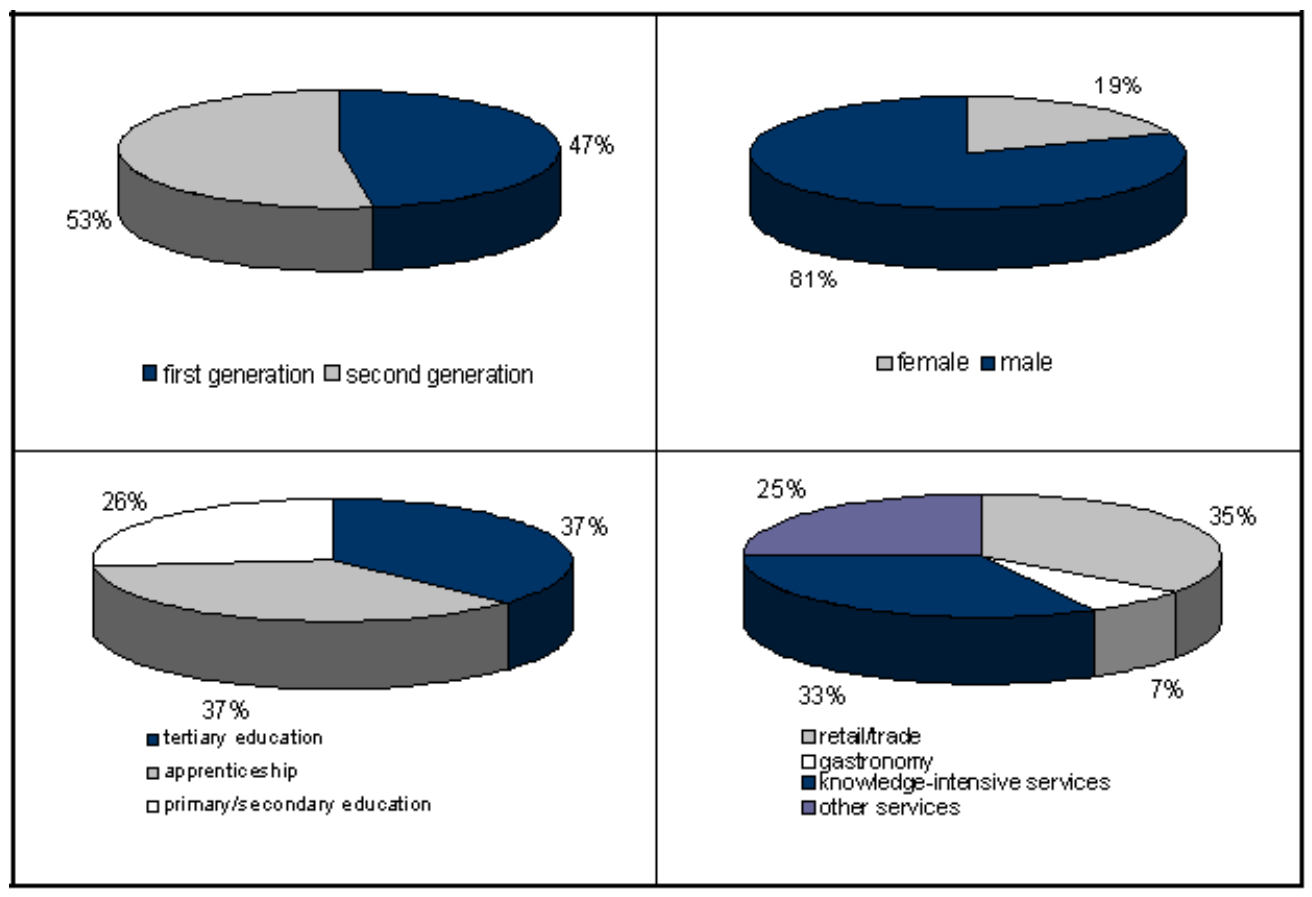

Source: own survey, 2008-2009, N=58

With several exceptions, all respondents were fluent in German. Hence, all interviews were conducted in German. In the other cases, a family member, usually active in the business, helped with the translation. Most interviews were conducted in the respondent's business and varied in length from 45 minutes to 2 hours. 


\section{Is (ethnic) social capital significant for Turkish entrepreneurs?}

Social capital has become a ubiquitous metaphor in social sciences, and has been invented and reinvented several times. As a result, consensus on a common definition remains elusive. However, despite conceptual variations following different research branches, most of the definitions tend to converge towards the understanding of social capital as a resource, which is individually available but which occurs only in, and through relations with others. According to Coleman(1988, p.98) social capital 'inheres in the structure of relations between actors and among actors'. It particularly refers to aspects of the social structure that facilitate trust and collective action such as norms, networks and social relations.

In most of the studies dealing with migrant entrepreneurship, the concept of social capital has been reduced to an ethnic resource, being allocated to any entrepreneur belonging to a specific ethnic group. Its understanding is mainly related to the structure of the ethnic community in terms of the existing ethnic resources, moral obligations and opportunities. Moreover, ethnic social capital has been treated as a static group characteristic, being analyzed in close relation with the size of migrant communities having the same ethnicity or country of origin. The presumption has been that there is, for example, 'one Turkish community' and that each person with a Turkish background is part of it, having equal access to the available ethnic resources.

The present analysis moves away from this approach and points out that the concept of social capital translated in terms of membership in an ethnic group, ignores crucial information on individuals' choices and the strength of their belonging to that specific group. As Constant et al. (2006, p.1) notes, the classification of an immigrant as 'ethnically Turkish' based solely on his citizenship or Turkish background is particularly problematic, as it 'leaves out crucial information on how culturally, socially and psychologically committed to the Turkish ancestry and values this immigrant is'.

In line with the work of Chaganti and Greene (2002), the social capital of migrant entrepreneurs is in this article considered to be unequally distributed, reflecting the different grades of attachment between migrants and their ethnic community. The stock size of co-ethnic peers is not decisive, but rather the intensity of the interpersonal relation flows. The level of personal and business involvement in the ethnic community is considered to be a better indicator of ethnicity than the reported ethnic grouping, which is a mere demographic identification. Therefore, when questioning the extent to which an entrepreneurs' social capital is ethnic, this analysis 
does not look at the ethnic background as such, but concentrates on aspects such as the composition of the circle of friends, the structure of the employees, clients and suppliers, the role played by the closest ethnic ties in the business process, and voluntary membership in (ethnic) organizations.

The survey conducted with 58 Turkish entrepreneurs reveals a heterogeneous picture regarding ethnic social capital and consequently, indicates different attachment grades to the local Turkish community. Though the quantitative analysis seems to confirm the existing body of literature, a more differentiated view based on a qualitative approach brings several new perspectives.

An important element in analyzing the structure of social capital concerns the environment, both private and professional, in which migrant entrepreneurs operate. The entrepreneurs interviewed in the present survey seem at first sight to embed their activities in a predominantly ethnic environment. Privately, almost 30 percent of the business owners are likely to spend their spare time with Turkish fellows and more than half with fellows of different nationalities. Only 20 percent of respondents claim to have a private circle of friends predominantly made up of Germans.

When further analyzing the structure of their employees, clients and suppliers the situation does not change much: almost 60 percent of the survey respondents hire employees with Turkish backgrounds, 40 percent address exclusively a Turkish clientele with their products and services and more than half work with Turkish suppliers or suppliers having a migrational background.

Table 1: Employees, suppliers and clients structure of Turkish businesses in \% (survey sample)

\begin{tabular}{lccc}
\hline & Employees & Suppliers & Clients \\
\hline \hline Predominantly Turkish & 58.8 & 14.58 & 39.7 \\
Mixed & 35.3 & 31.25 & 29.3 \\
Predominantly German & 3.9 & 12.50 & 31.0 \\
Not applicable & 2.0 & 41.67 & - \\
Total & 100.0 & 100.0 & 100.0 \\
\hline
\end{tabular}

Source: own survey, 2008-2009, N=58

Note: the high percentage of the respondents stating to have no suppliers (not applicable) is explicable by the existence in the sample of 20 of entrepreneurs working in knowledge intensive sectors such as lawyer, physicians, or advisers/consultants.

Although these results might roughly illustrate the overall situation and confirm the existing body of literature, the picture becomes more puzzling when one ana- 
lyzes the structure of employees, clients and suppliers differentiated by the sectors of activity and migrational background of the entrepreneurs. A closer look reveals an antithetic pattern: particularly the entrepreneurs working in the retail, trade and gastronomy sector have indeed a Turkish private environment. This can be explained by their background: in most of the cases they are first generation migrants, with Turkish educations and with only average proficiency in German. However, due to economic reasons, such as the acerbic competition with fellow countrymen who offer the same products or services at lower rates, these entrepreneurs tend to build a mixed business environment. They increasingly attract a diverse clientele, and work with suppliers and employees having nationalities other than Turkish.

On the other hand, entrepreneurs belonging to the second generation (with higher educations completed in Germany, and often working as lawyers, physicians or advisors) are often privately embedded in a German circle of friends. However, they are the ones who most often invest in an ethnic business environment by deliberately approaching a Turkish clientele and by hiring Turkish employees, often people who can compensate for their own poor Turkish language skills.

A further element of social capital often addressed in the literature as being crucial for the development of migrant enterprises is the assistance of family and close kinship, as they provide financial capital and labor force. The present survey supports to a large extent the previous findings: almost 30 percent of all respondents did receive help from their families when founding their business, and 75.5 percent have at least one member of the family involved in their daily business activities. Furthermore, one third of the entrepreneurs relied exclusively on family capital and another 25 percent partly financed their business start-ups with funds from the family.

Figure 2: Family and kinship' s role in Turkish businesses, in \% (survey sample)

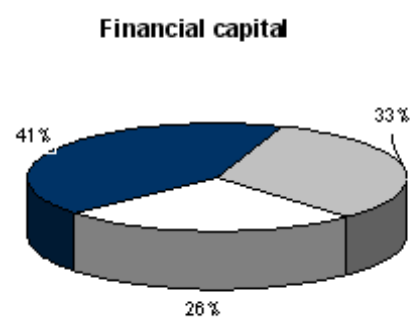

Dfinancial capital exdus evily from the farnily 口financial capital not exclus evily from the farr

no financial capital fr orn the farnily
Running the business

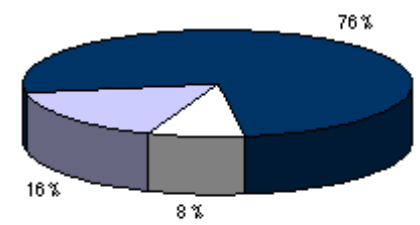

Whep from family $\square$ hep from others 口no help
Founding the business

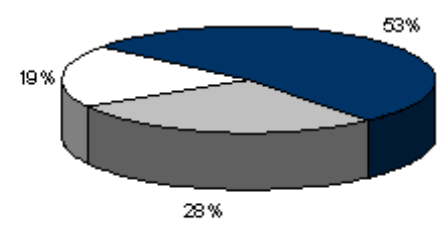

Dhelp from farnily Dhelp from others

ロno help

Source: own survey, 2008-2009, N=58 
However, family networks are not an asset for all migrant businesses. Again, the picture is more differentiated when considering the sectors of activity and the educational background of the owner. While the family, indeed, is important for those founding small businesses in the retail, trade and gastronomy sectors, it does not play much of a role for businesses established in knowledge intensive sectors. This can be explained by the fact that those migrants becoming self-employed in these branches tend to be better integrated in mainstream society and, therefore, are more knowledgeable of, and better able to access financial structures such as banks or other funding offices. Another reason for the lower involvement of family members in businesses founded in knowledge intensive sectors is that most of the occupations available in such branches require special knowledge and competencies. As a consequence, business owners have to hire qualified personnel who, in most cases, are not available in the family circle.

Finally, when looking at voluntary membership in associations, almost half of the survey respondents are not involved in any kind of such activities. The entrepreneurs who are engaged privately or professionally in associations tend to be those with a higher education level and who offer knowledge intensive services. In most cases, they regard their engagement as a possible means of establishing contacts with other entrepreneurs or with potential clients. However, there were also situations in which the involvement was regarded not only as a strictly business matter, but also a modality of socializing within the ethnic community. Particularly those entrepreneurs who are active in Turkish associations described their membership as a matter of civic responsibility, as they try to promote a positive image of their community and assume for themselves a role model function for the younger generation.

\section{Ethnic social capital as a matter of bounded rationality}

The figures presented so far point out that, though ethnic social capital seems at first to be crucial for Turkish entrepreneurs, this does not hold true for all business owners. The reasons for the different importance attached to ethnic social capital are two fold: firstly, as previously shown, Turkish entrepreneurs are not all equally rooted in the local ethnic community. Though they share the same ethnic background, not all entrepreneurs have the possibility - or are able - to activate ethnic resources. Secondly, their involvement in the ethnic community is not a static occur- 
rence determined by their nationality as such, but is much more driven by economic considerations. While some entrepreneurs, whether out of necessity or strategy, have to or want to activate ethnic resources, others chose to rely on alternatives from outside the ethnic community.

The understanding of social capital as a resource for economic action has not yet found much attention in migrant entrepreneurship research. Following the tradition started in the early 70s by Light (1972) and Bonacich (1973), the underlying tenor of the academic debate is that the cultural background and the available ethnic social capital govern the behavior of its inheritors, making them act or react in certain ways. In a large branch of migrant entrepreneurship literature, ethnic social capital is considered to be available in the ethnic community prior to the entrepreneurial activity. Its existence and amount are said to substantially influence the business decisions of the ongoing entrepreneurs regarding their sector of activity, financial sources, and the make-up of their clients, suppliers and employees.

This point of view is to a large extent compounded by the homo sociologicus approach encountered in modern sociology. It conceptualizes individuals as being 'over-socialized,' i.e. they are overwhelmingly receptive to the opinions of others and blindly follow unwritten codes of behavior developed and internalized through social interactions, without perceiving them as constraints. Brown(1977, p.17) describes the homo sociologicus approach as deriving from the assumption that people act in "certain ways because to do so is customary, or an obligation, or the 'natural thing to do,' or right and proper, or just and fair". Coleman (1988, p.96) regards it as a perspective where "the individual is shaped by the environment, but there are no internal springs of action that give the actor a purpose or direction". The 'atomization' of individuals addressed by Coleman in his critique represents the main shortcoming of this approach. This results from the assumption that the individual is so deeply embedded in networks of interpersonal relations, that in actual decision making situations his behavior becomes automatic (i.e. the subject has already internalized all social influences, and therefore ongoing social relations and structures become irrelevant; Granovetter, 1985).

For a long time, the analyses based on the idea of homo sociologicus have demonstrated their relevance in explaining and predicting essential features of entrepreneurial activity. However, while these models address business patterns depicted by entrepreneurs belonging to first generation migrants, they do not offer any fresh in- 
sights regarding entrepreneurial changes, relevant particularly for second generation migrants.

Following the argumentation so far, one would tend to address the issue of migrant entrepreneurship from a perspective much more closely related to economics. Though, the rational choice framework in its primal form cannot explain the complex phenomenon of migrant entrepreneurship and its relation to ethnic social capital. This shortcoming results from the fact that the homo oeconomicus approach, as a fundamental assumption of classical and neoclassical economic theory, operates with a rather 'under-socialized' concept of human action (Granovetter, 1985). The individuals are described as being self-regarding, utility-maximizing, and as having stable and consistent preferences. By definition, the effects of social interactions in the decision-making process are not considered to be key factors in the economic analysis, and only 'rational' factors are taken into account. In light of this tradition of thought, the fact that individual behavior might be influenced by social relations has been treated, if at all, by many economists as a frictional drag that impedes competitive markets, and not as a potential factor which might explain economic outcomes. In a nutshell, the basic assumption of this economic stream is that people's decisions are more likely to rest on rationality and long term interests, and not on their neighbors' or friends' thoughts about what is desirable. It is obvious that this view of human behavior cannot account for the complex environment in which entrepreneurs are embedded, as it theoretically reduces the individual to an entity existing within a social and institutional vacuum.

In response to these classical approaches, Granovetter (1985) elaborated on the concept of 'embeddedness'. This perspective takes into account the economic and social context in which migrant entrepreneurs embed their activity. However, one critique of embeddeness is that it neglects the politico-institutional context in which migrant entrepreneurs operate. Rath and Kloosterman (2000) addressed this issue by further developing the concept of 'mixed embeddedness'. They argue that beyond cultural-ethnic and socio-economic factors, one also has to take into consideration the interplay between the supply and demand sides when explaining certain patterns of entrepreneurial activity. The demand side (including the opportunities available on the market, national institutions and regulations) determines when, where and to what extent migrants engage in certain entrepreneurial activity, and which ethnic resources they will activate in order to achieve their goals (Rusinovic, 2006). In 
other words, the entrepreneurial behavior of migrants is not only subject to economic incentives and social-cultural determinants, but is also restricted to the institutional framework they operate in.

This understanding of individual behavior is to some extent related to the concept of 'bounded rationality' put forth by social scientists such as Herbert Simon as early as the mid-1950s. This theory outlines the idea that the rationality of individuals - and implicitly their actions - is limited by the information and finite amount of time they posses, their cognitive abilities and the continuous changing and insecure environment they live in. According to the bounded rationality approach individuals' decisions are not always based on long term considerations, and do not necessarily account for synergies from other related fields (Simon, 1993, p.2).

\subsection{Empirical results}

The interviews conducted with Turkish business owners in Hamburg revealed an understanding of social capital which stands in contrast with the mainstream perspective, which sees the entrepreneur as being governed by his social relations. Rather, social capital is perceived by migrant entrepreneurs in line with an approach comprising both the works of rational choice scholars such as Coleman (1990) and Becker (1996) and the bounded rationality theory of Simon (1993). Coleman's concept of social capital presumes the existence of rational individuals who act in order to maximize their utility. He asserts that human behavior is in the first instance a matter of investment and returns. Factors such as ethnicity, cultural background or altruism are not the prime determinants of action; they are part of the utility function, but with a lower weight than so far assumed. Coleman reshapes the individual with an engine of action (the 'economic rational choice of self-interest') and defines social capital mainly according to its function, and not its form.

The picture of migrant entrepreneurs as bounded rational actors, who use their social capital according to their economic needs, becomes clear when taking a deeper look at the business structures existing in their enterprises.

As presented in the latter section, most of the personnel employed in the surveyed businesses were Turkish. The motivations behind hiring people with Turkish background are diverse in nature, but, in contrast with the assumptions described by the cultural and ethnic approaches, they all follow economic considerations and are in the end a matter of rational choice. 
The entrepreneurs who are active in the retail, trade and gastronomy sectors, and particularly those belonging to the first generation, often hire co-ethnics because of their poor German language skills. Their decision is driven by the necessity that they create common ground to facilitate cooperation in the workplace, while reducing communication costs. In this case, however, the reliance on the ethnic work force is not necessarily in accordance with the entrepreneur's desires, rather it much more reveals the lack of other possibilities. As Pecoud (2004) observes, for many entrepreneurs working with co-ethnics means going through a process of 'ethnicisation.' While in their previous employment history as employees most of the entrepreneurs likely had a predominately German environment, now they are forced into a situation in which they must work with other Turkish people.

Language and communication skills are not the only reason why some Turkish entrepreneurs hire co-ethnics. In a lot of cases, due to budget constraints, it is simply more cost efficient to employ family members or relatives than external employees. In such cases, the salaries are very often not stipulated in a formal contract, but are made subject to the economic fluctuations of the business. Moreover, co-ethnics and family members are often willing to work on a schedule which would hardly be acceptable for other employees.

In other cases, according to the surveyed business owners, Turkish staff is more appropriate than employees with another nationality, both because of the unique skills and cultural competencies they bring with. This is particularly relevant for businesses offering products which demand a certain cultural and religious knowledge in the preparation process, e.g. helal-butcheries or the manufacture of sweets without the use of gelatin. Furthermore, the employment of co-ethnics for such sensitive jobs encourages the clientele's trust and faith in the quality of the goods, which implicitly has to be provided by entrepreneurs in order to keep their customer base.

While, as presented thus far, entrepreneurs' reliance on an ethnic workforce represents a necessity for some, the opposite is true for entrepreneurs who are active in knowledge intensive sectors, and who belong to the second generation of migrants. In their cases, the employment of co-ethnic represents a strategy: in order to attract and maintaining their Turkish clientele it is convenient to have personnel who can understand both the language and mentality of the customers. Almost all lawyers and physicians with Turkish background interviewed in the survey mentioned certain competencies such as open-mindedness and intercultural empathy which they 
value when they look for employees. Moreover, Turkish language proficiency was mentioned as being particularly important in the contact with clients. As most of these entrepreneurs are embedded in a predominantly German environment, a basic job assignment for the staff is to compensate for their poor Turkish language skills:

Turkish language is prerequisite for the employment here; because otherwise the employees can not build a trust relationship with the clients. (Turkish lawyer, 39 years old)

However, the economic benefits of hiring an ethnic work force (in terms of reduced communication and personnel costs or customer acquisition and support) can also turn into disadvantages. Some survey respondents stated that they deliberately do not want to hire Turkish personnel as the common background could be evoked by the employees as an excuse for unprofessional behavior in the workplace.

Moreover, especially those entrepreneurs who have a predominantly German or diverse clientele try to avoid labeling themselves as being 'Turkish.' By hiring only co-ethnics, they are afraid they would lose other clients who might not feel comfortable in a strictly Turkish environment. Thus, they strategically employ people from a diverse background in terms of nationality, age or gender. This business strategy is applied particularly by entrepreneurs who have their businesses located in neighborhoods that are internationally oriented or have a predominantly German population. Interesting is the case of some Turkish greengrocers who chose to fade out their ethnic background and instead to present themselves as being 'Mediterranean.' In the belief that southern European flair would sell much better than a traditionally Turkish atmosphere, they have adapted their marketing strategy to the neighborhood clientele by offering a mixture of high quality, expensive, Mediterranean products, and by using Italian vocabulary when approaching the clients. Similar is the case of some entrepreneurs whose businesses are located in the 'Schanzenviertel,' one of the trendiest areas in Hamburg, with a predominantly young and alternative population. In order to be in line with the spirit of the neighborhood and to attract more customers, the owners try to create an international and fashionable atmosphere in their shops by offering original products or services, and by employing young people from diverse backgrounds. In their opinion, Turkish employees would reflect an overly traditional appearance, which would not be appropriate for the given environment.

Other business aspects that highlight the economic side of ethnic social capital refer to the structure of clients and suppliers. 
When concentrating on a certain clientele or when selecting adequate suppliers, migrant entrepreneurs - in contrast with the assumptions put forth by the mainstream literature - seem to be more concerned with their economic fate than with ethnicity as such. Although a large amount of the surveyed entrepreneurs do approach exclusively a Turkish clientele and therefore work predominantly with Turkish suppliers, their motivations are not bounded to ethnic arguments such as common cultural background, solidarity and fraternity with, or responsibility for the ethnic community. Their motivations rather follow economic reasoning: they are demand oriented in terms of how to satisfy and increase the clientele, and are supply oriented in terms of picking up suppliers who provide low-cost, quality products, regardless of their nationality.

Particularly the second generation migrant entrepreneurs active in knowledge intensive sectors approach a Turkish clientele in most of the cases as part of an elaborated strategy. Their business concepts rest on the identification of a new market niche, i.e. the professional counseling of people with migrational background living in Germany. This strategic focus on co-ethnics was well thought-out by some respondents long before their entrance into the labor market. The decision regarding the appropriate field of study, and later on their occupational choice, was made in conjunction with the exploitation of an advantage in terms of language and mentality not available to their German colleagues.

This was basically the fundamental element of the concept. Otherwise I would not have had the courage to take this step. It was the fundamental element of the concept, because already at that time, back in 1999, the market for lawyers was saturated. And as a new entrant one has few changes if he doesn't distinguish himself from the others. And this was basically my profile; I chose to serve a market which was not available for Germans.(Turkish lawyer, 40 years old)

Following these strategic considerations, almost all survey respondents providing knowledge intensive services started early on, during their university studies or afterwards, to invest in their ethnic social capital. While some of them deliberately re-activated old family networks (if available), others tried to build up their ethnic networks by posting commercials in Turkish mass media or by engaging in Turkish associations.

However, the identification and use of this new niche does not solely mark a strategic business decision of the second generation migrant entrepreneurs. In some 
cases, it signals a lack of competitiveness: as some of the survey respondents stated, the German market is saturated with lawyers and law offices. Under these conditions, it is even more difficult for lawyers with a Turkish background to approach a German clientele and compete for the same customers with their German colleagues. In order to assure the existence of the business, they have no other choice but to concentrate on a Turkish clientele. Nevertheless, in these situations, the business decisions are as well guided by economic aspects and not by ethnic motivations.

The same fundamental economic motivation can also be identified when analyzing, in detail, the business activities of migrants providing low skilled services. However, the circumstances are insofar different as their incentives are more frequently driven by the lack of other opportunities than by recognition of market opportunities. Often it is the case that the entrepreneurs' strategies are limited to the information which circulates in the ethnic community. In this respect, there is a lack of perspective and incentive to build up a business or to invest in a new business field. Traditional shops and professions are learned from the first generation entrepreneurs and are in a similar manner continued by young business owners. To this end, migrant entrepreneurs must act in an environment limited to a certain set of opportunities, information and resources. Though their decisions are in a strict manner still rational, they are reduced (bounded) and as such it is predetermined that they will reach the second best solution.

Another sign of this lack of perspective is represented by the imitation of successful enterprises: if a business concept seems profitable, it is very likely that another entrepreneur will open the same shop, offering similar products at lower prices. Though incorporating elements of economic strategy, this practice is not a sign of entrepreneurial behavior in a Schumpeterian sense, but rather a sign of limitation and vulnerability. The self-employment activity remains, therefore, in many cases the ultimate solution for escaping unemployment. 


\section{Crossing the boundaries: migrant vs. native entrepreneurs}

Against this background, an issue which has often been analyzed in the literature on migrant entrepreneurship is the comparison between native and migrant businesses. The leading discourse posits that particularly the motivation to become self-employed, as well as several other features of migrant businesses such as the determination of the sector of activity, financial sources, employment structure and survivability, are different than in the case of native entrepreneurs. The explanations for these discrepancies range from cultural and ethnic aspects to legal arrangements, language barriers and discrimination. The emphasis of most studies is set on the role played by cultural factors and ethnicity. However, as illustrated in the previous chapters, ethnicity as such has little relevance for migrant entrepreneurs in the actual business decisions. The ethnic social capital is, if at all, used strategically to achieving economic goals.

Within this context, the questions of whether and to what extent migrant business owners are different in their entrepreneurial behavior than their German counterparts should be reconsidered. Furthermore, it is questionable whether the assignment of certain entrepreneurs with migrational backgrounds - particularly second generation migrant entrepreneurs - to the group of 'migrant entrepreneurs' remains applicable.

When approaching the interviewees for this survey, it was often the case that they did not feel eligible to respond to the questions. They perceived themselves simply as entrepreneurs, and rather disliked the denomination of 'migrant entrepreneur.' Apart from the entrepreneurs' own perceptions, the analysis of several statistics also point out that migrant entrepreneurs and their businesses, disentangled of the ethnic component, act in a similar manner as German business owners.

Regarding the motivation for founding businesses, it is often assumed that migrant entrepreneurs are more likely to become self-employed due to their lacking other opportunities and the higher unemployment rates they face on the labor market. However, a survey conducted yearly by theKfW-Bankengruppe $(2007)^{2}$ points out that, among all surveyed persons who founded a business in 2007, 43.6\% stated that the foundation of the business was not their dream but occurred much more out of need, as they did not have any other options on the labor market. The rest $(56.4 \%)$ stated that they regarded self-employment as an opportunity. These figures show that turning to entrepreneurial activities out of necessity is not typical for migrants, but concerns all entrepreneurs, regardless of their nationality. 
Similarities between migrant and native businesses can be also found when one closely compares further features which have been thus far recorded as being specific only for the migrant case. Myths such as the lack of information concerning counseling opportunities or the extensive role played by the ethnic networks (including family members and acquaintances) as advisory structures are countered by the existing statistics:

Table 3: Comparison migrant vs. German businesses

\begin{tabular}{lcc}
\hline Use of counseling structures: & Migrants & Germans \\
\hline \hline No counseling & 6.2 & 10.0 \\
Counseling through Banks & 9.3 & 11.1 \\
Chamber of Commerce/Chamber of Skilled Crafts and Small Businesses & 22.9 & 26.7 \\
Internet & 41.0 & 45.5 \\
Friends/Family/Acquaintances & 65.8 & 53.4 \\
Other self-employed/Founder's networks & 34.8 & 26.7 \\
Federal Employment Agency & 29.1 & 26.9 \\
\hline
\end{tabular}

Source: KfW Bankengruppe, 2007

Note: multiple choices possible

The empirical evidence stemming from the conducted interviews supports these statistics. The use of social capital for business activities is equally prevalent among both migrant and native entrepreneurs:

...Advertising for the own business through memberships in associations and business clubs... I do not think that Turkish lawyers handle differently than Germans. Because for both of us, solely some announcements or name logos on the street would definitely not be enough to draw the attention of clients. (Turkish lawyer, 38 years old)

However, while migrant businesses tend to become increasingly similar to businesses founded by natives, this process is not likely to occur for all migrant entrepreneurs, being subject to variations according to the educational level and, implicitly, sector of business. The survey conducted with Turkish entrepreneurs reveals, for example, that this convergence process is indeed occurring in the case of second generation migrants, particularly for those active in knowledge intensive sectors. In the sectors of activity demanding a lower level of formal qualifications and skills, there are still some patterns such as language barriers which are, indeed, migrant specific.

Nevertheless, the survey results underline the fact that in the differentiation of migrant and native businesses, the essential role is not played by cultural and ethnical 
factors - and even less by (ethnic) social capital - but by the individual characteristics of business owners, especially by their formal educational background and/or the level of their professional competency.

In line with these ideas, it becomes obvious that the delimitation between migrant and native entrepreneurs must be reconsidered. Though aspects related to the nationality of the entrepreneurs might still provide essential insights, an analysis differentiating business owners according to their educational background could bring a fresh perspective both for researchers and policy makers.

\section{Conclusions}

"Explanations for every aspect of immigrant entrepreneurial behaviour are directly related to ethnocultural traditions, ethnic moral frameworks and ethnic behaviour patterns, ethnic loyalties or ethnic markets. Thus, they reduce immigrant entrepreneurship to an ethnocultural phenomenon existing within an economic and institutional vacuum"(Rath and Kloostermann, 2000, p. 666).

Following the critique expressed by Rath and Kloosterman (2000), this paper brings a new perspective to the existing body of literature by analyzing migrant entrepreneurs from an economic perspective. The underlying assumption of the study is that the ethnic component of migrant entrepreneurship, and particularly the importance of ethnic social capital, has been constantly overestimated by researchers.

The empirical research based on 58 recent qualitative interviews with Turkish entrepreneurs challenges the mainstream discourse by inquiring how and to what extent ethnicity and the cultural background of migrant business owners play a relevant role in their entrepreneurial activity. The analysis brings to light a number of relevant aspects, which have been so far neglected in the ongoing academic debate.

Firstly, when analyzing the relationship between migrant entrepreneurship and the ethnic social capital, one has to keep in mind that the existing ethnic resources are not available to the same extent for all entrepreneurs, though they share the same ethnic background. While some of the business owners tend to embed their private and professional matters in an ethnic environment, and can therefore easily activate their ethnic social capital, other entrepreneurs manage their activities in rather diverse or predominantly German surroundings and do not have the same access to ethnic resources. The latter situation occurs especially in the case of second generation migrant entrepreneurs with a higher educational level, who have been less 
socialized during their studies within the local ethnic community.

Secondly, ethnicity and cultural background do not represent an asset for migrant entrepreneurs per se. The ethnic social capital emerging out of social interactions with co-ethnics becomes relevant for migrant business owners only in the moment when it is implemented in business activities. In line with this idea, ethnic social capital, contrary to the approach existent in the current body of literature, should be seen as an economic resource for action and not as an ethnic given. The interviews have revealed that migrant entrepreneurs do not value and use their ethnic background and their ethnic social capital out of identification or solidarity with their co-ethnics, rather they strategically implement them, like any other entrepreneurs, in the daily business process. As Pecoud(2004, p.12) puts it: "business is business: shop owners are understandable concern with their economic fate and are not obsessed with ethnicity and identity matters". However, though in a strict manner incentive-oriented and rational, the behavior of certain migrant entrepreneurs, in particular those providing low skilled services, is bounded by a set of available opportunities and information and is therefore reduced to the second best economic option.

Finally, the paper has raised the question of the extent to which migrant entrepreneurs, classified as such solely according to their ethnic background, are different than their German counterparts. When leaving out arguments such as different cultural backgrounds, available ethnic social capital or embeddedness in ethnic networks, a large fraction of migrant entrepreneurs run their businesses in a similar manner as native entrepreneurs. Within this context, new research approaches in which entrepreneurs are analyzed according to their educational background or past professional experience can offer more fruitful research result.

\section{Notes}

\footnotetext{
${ }^{1}$ For several reasons, in the case of migrant entrepreneurs in Hamburg it is not possible to draw a representative sample. The first impediment is not specific to Hamburg, but rather results from the general German procedure of drawing statistics on migrants according to nationality. This makes it impossible to identify naturalized persons or people with a past migration experience, since they are registered officially as German nationals (Liebig/OECD, 2007). Furthermore, the German legal framework regarding data gathering is particularly sensitive and restrictive. As there is no specific body in charge of their economic integration, information on the performance and status of people with migrational backgrounds is not explicitly collected. As a consequence, when trying to analyze and to asses the number of migrant entrepreneurs one has to rely on a mixture of sources, which is barely complete and significant. Due to these limitations regional analyses, as in our case regarding the city of Hamburg, are particularly problematic. While data sources such as the Microcensus or the GSOEP do not offer enough observation on the municipality level, local statistics are rather unreliable due to deficient data collection procedures.
} 


\begin{abstract}
${ }^{2} \mathrm{KfW}$-Bankengruppe is a promotional bank under the ownership of the Federal Republic and the Länder (federal states). The analyses performed by KfW's Department of Economics focuses on small and medium-sized enterprises in Germany. In particular, these analyses take the form of examinations based on KfW's own data, carried out in order to draw an empirically based picture of the economic situation of SMEs in Germany.
\end{abstract}

\title{
References
}

Aldrich, H. E. and Waldinger, R. (1990). Ethnicity and Entrepreneurship, Annual Review of Sociology 16: 111-135.

Basu, A. and Goswami, A. (1999). Determinants of South Asian Entrepreneurial Growth in Britain: a Multivariate Analysis, Small Business Economics 13(1): 57 -70 .

Bates, T. (1994). Social Resources Generated by Group Support Networks May Not Be Beneficial to Asian Immigrant-Owned Small Businesses, Social Forces 72(3): $671-689$.

Becker, G. (1996). Accounting for Tastes, Harvard University Press.

Bonacich, E. (1973). A Theory of Middleman Minorities, American Sociological Review 38: 583-594.

Brown, H. P. (1977). The Inequality of Pay, Oxford University Press.

Chaganti, R. and Greene, P. G. (2002). Who Are Ethnic Entrepreneurs? A Study of Entrepreneurs Ethnic Involvement and Business Characteristics, Journal of Small Business Management 40(2): 126 - 143.

Coleman, J. S. (1988). Social Capital in the Creation of Human Capital., American Journal of Sociology 94: 95-120.

Coleman, J. S. (1990). Foundations of Social Theory, Belknap Press of Harvard University Press.

Constant, A., Gataullina, L. and Zimmermann, K. F. (2006). Ethnosizing Immigrants, IZA Discussion Paper No. 2040.

Granovetter, M. (1985). Economic Action and Social Structure: The Problem of Embeddedness, Amercian Journal of Sociology 91: 481-510.

KfW-Bankengruppe (2007). Unternehmensgründungen von Personen mit Migrationshintergrund, Technical report, KfW Bankengruppe. 
Liebig, T. (2007). The Labour Market Integration of Immigrations in Germany, OECD Social, Employment and Migration Papers No. 47.

Light, I. (1972). Ethnic Enterprise in America, Berkeley: University of California Press.

Light, I. and Bonacich, E. (1988). Immigrant Entrepreneurs: Koreans in Los Angeles, 1965-1982, Berkeley: University of California Press.

Pecoud, A. (2004). Entrepreneurship and Identity: Cosmopolitanism and Cultural Competencies among German-Turkish Businesspeople in Berlin, Journal of Ethnic and Migration Studies 30(1): 3 - 20.

Portes, A. and Rumbaut, R. (2001). Legacies: the Story of the Immigrant SecondGeneration, New York: Russell Sage Foundation.

Portes, A. and Sensenbrenner, J. (1993). Embeddedness and Immigration: Notes on the Social Determinants of Economic Action, The American Journal of Sociology 98: $1320-1350$.

Rath, J. and Kloosterman, R. (2000). Outsiders' Business : A Critical Review of Research on Immigrant Entrepreneurship, International Migration Review 34(3): 657 $-681$.

Rusinovic, K. (2006). Dynamic Entrepreneurship: First and Second-generation Immigrant Entrepeneurs in Dutch Cities, Amsterdam University Press.

Simon, H. A. (1993). Homo rationalis: die Vernunft im menschlichen Leben, Frankfurt am Main: Campus.

Waldinger, R., Aldrich, H. and Ward, R. H. (1990). Ethnic Entrepreneurs: Immigrant Business in Industrial Societies, Sage Publications.

Waldinger, R. D. (1986). Through the Eye of the Needle: Immigrants and Enterprise in New York's Garment Trades, New York University Press.

Zhou, M. (2004). Revisiting Ethnic Entrepreneurship: Convergences, Controversies, and Conceptual Advancements, International Migration Review 38(3): 1040 -1074 . 


\section{HWWI Research Papers}

by the HWWI Research Programme „Migration Research Group“

18. Selbstständige Migrantinnen und Migranten in wissensintensiven Dienstleistungsbranchen in Deutschland: Eine neue Nischenökonomie?

Ann-Julia Schaland | Hamburg, Juni 2009

17. Practices for Recognising Qualifications of Migrant Health Professionals and their Labour Market Integration - A Comparison of Practices in Five Countries

Tanja El-Cherkeh, Tamar Ramot-Nyska | forthcoming

16. Migrants in the Job Centre. Qualitative findings on migrants' experiences with Public Employment Support Services in Germany

Jan Schneider, Michael Fischer, Vesela Kovacheva | Hamburg, September 2008

15. Diversität und die Wirtschaft. Erfahrungen und Perspektiven von Migrantinnen und Migranten in Deutschland

Michael Fischer | Hamburg, Juni 2008

14. Cultural Diversity and Economic Performance: Evidence from European Regions

E. Bellini, G. Ottaviano, D. Pinelli, G. Prarolo | Hamburg, April 2008

13. Does citizenship matter? The economic impact of naturalizations in Germany Max Friedrich Steinhardt | Hamburg, April 2008

12. The Labor Market Impact of Immigration in Western Germany in the 1990's

Francesco D’Amuri, Gianmarco I. P. Ottaviano, Giovanni Peri | Hamburg, April 2008

11. Diversity Management and the Business Case

Michael Fischer | Hamburg, November 2007

10. Labour market entry of migrants in Germany - Does cultural diversity matter?, Anette Haas, Andreas Damelang | Hamburg, May 2007

9. Skills and remittances: The case of Afghan, Egyptian, and Serbian immigrants in Germany

Florin Vadean | Hamburg, April 2007

8. Rethinking the effects of immigration in wages

Gianmarco I.P. Ottaviano, Giovanni Peri | Hamburg, April 2007

7. Regional disparities in employment of high-skilled foreigners - Determinants and options for migration policy in Germany

Carola Burkert, Annekatrin Niebuhr, Rüdiger Wapler | Hamburg, March 2007

6. Social relations and remittances: evidence from Canadian micro data

Don J. DeVoretz, Florin Vadean | Hamburg, February 2007

5. Egyptian, Afghan, and Serbian diaspora communities in Germany: How do they contribute to their country of origin?

T. Baraulina, M. Bommes, T. El-Cherkeh, H. Daume, F. Vadean

Hamburg, January 2007

4. Arbeitsmarkt und Migration - eine empirische Analyse der Lohn- und Beschäftigungseffekte der Zuwanderung in Deutschland

Max Steinhardt | Hamburg, November 2006

3. Peer Effects, Social Multipliers and Migration at School: An International

Comparison

Horst Entorf, Martina Lauk | Hamburg, July 2006

2. The Impact of Student Diversity in Secondary Schools. An Analysis of the International PISA Data and Implications for the German Education System

Katharina Michaelowa, Jean Bourdon | Hamburg, July 2006 
1. Migration and Innovation. Does Cultural Diversity Matter for Regional R\&D Activity?

Annekatrin Niebuhr | Hamburg, July 2006 
The Hamburg Institute of International Economics (HWWI) is an independent economic research institute, based on a non-profit public-private partnership, which was founded in 2005. The University of Hamburg and the Hamburg Chamber of Commerce are shareholders in the Institute .

The HWWI's main goals are to:

- Promote economic sciences in research and teaching;

- Conduct high-quality economic research;

- Transfer and disseminate economic knowledge to policy makers, stakeholders and the general public.

The HWWI carries out interdisciplinary research activities in the context of the following research programmes: Economic Trends, Hamburg and Regional Development, World Economy and Migration Research Group. 
Hamburg Institute of International Economics (HWWI)

Heimhuder Str. 71 | 20148 Hamburg | Germany

Phone +49 (0)40 340576 - 0 | Fax +49 (0)40 340576 - 776

info@hwwi.org | www.hwwi.org 